\title{
Application of the lateral angle method for sex determination of cremated individuals from burials of the Lusatian culture cemetery in Czernikowice, Poland
}

\author{
Agata Hałuszko',2, Maciej Guziński ${ }^{3}$ \\ ${ }^{1}$ Archeolodzy.org Foundation, Wrocław, Poland \\ ${ }^{2}$ Institute of Archaeology, University of Wrocław, Wrocław, Poland \\ ${ }^{3}$ Department of General and Interventional Radiology and Neuroradiology, \\ Wrocław Medical University, Wroclaw, Poland
}

ABSTRACT: Research of cremated human remains are limited by severe analytical constraints. Estimation of basic anthropological parameters such as sex of individuals or their age at death is often uncertain. A method for assessing the sex of cremated individuals measures the lateral angle of the petrous part (PP) of the temporal bone, known as the lateral angle (LA) method.

In the cemetery of the Lusatian culture in Czernikowice $\left(51.317389^{\circ} \mathrm{N}, 15.871469^{\circ} \mathrm{E}\right), 6$ well-preserved PP were identified. The analyzed PP belonged to 6 different individuals: 3 adults and 3 children. Based on standard anthropological methods, sex was estimated for adults individuals: 2 males and 1 female. The identified PP served as the basis for application of the LA method. The bones were scanned by computed tomography $(\mathrm{CT})$ and the tomographic imaging allowed measurement of the lateral angle.

The absolute values of intra-observer errors did not exceed $1^{\circ}$. Relative technical errors of measurements (rTEM) fell in the range below 5\%, which is indicative of their high precision. Individuals for which the LA value was greater than or equal to $45.0^{\circ}$ were qualified as females and those for which it was less than $45.0^{\circ}$ - as males. The LA values for female individuals ranged from 48.0 to $49.1^{\circ}$, (average $48.5 \pm 0.78^{\circ}$, median $48.4^{\circ}$ ) and for male individuals were in the range of $24.9-37.5^{\circ}$ (average $33.4 \pm 5.80^{\circ}$, median $35.5^{\circ}$ ). The absolute difference between the average values for female and male individuals was considerable $\left(15.1^{\circ}\right)$ and statistically significant $(p<0.001)$.

The LA method provides good reliability of measurements when it comes to this analysis with regard to cremated osteological material, and the use of non-invasive CT enhances its value in the context of archaeological remains. However, its capability for sexing subadult individuals should be approached with caution and requires further research.

KeY WORDS: LA method, computed tomography, cremated human remains, Urnfield culture, Late Bronze Age 


\section{Introduction}

When pursuing the research on communities connected with the Urnfield tradition on the present-day territory of Poland, we face a large-scale spatio-temporal phenomenon; duration of some cemeteries extended for over one thousand years (Lasak 1996; Stolarczyk et al. 2020). Identification of variability of biological parameters of prehistoric communities is crucial for analysing consequences of their cultural progress based on the evolution of adaptative mechanisms within the population. Accordingly, anthropological data can be of fundamental importance for socio-cultural inferences and changes in funeral rites. The current progress in anthropological methods based on advanced technology provides new information that is especially important in the research on populations of the Urn field culture, as their communities commonly used cremation in their burial practices.

Investigations of cremated bioarchaeological materials are limited by considerable analytical constraints. Estimation of basic anthropological parameters such as sex of individuals or their age at death is very often uncertain. This is particularly true for assessing the sex of individuals on the basis of cremated bone fragments (McKinley 2015). Cremated remains are generally considerably fragmented and deformed, which makes it impossible to use the methods of sex determination that apply to skeletal materials (Strzałko et al. 1973; Dokládal 1999; White et al. 2011). The methods of estimating sex of subadult individuals based on morphology of the mandible and ilium (Schutkowski 1993; Loth and Henneberg 2001), as well as biochemical methods (Rebay-Salisbury et al. 2020; Gowland et al. 2021), cannot be applied to cremains. Of the methods employed for sexing adult individuals, the use of both the descriptive as well as metric ones can result in errors due to a variety of changes in shape and dimensions of particular parts of a skeleton in the process of cremation (Strzałko et al. 1973).

Petrous parts of temporal bones (PP) are among bones with the best preservability (Masotti et al. 2013; Bonczarowska et al. 2021). Therefore, several methods of sexing were developed which use measurements of different anatomical structures constituting PP (Wahl 1981; Schutkowski and Herrmann 1983; Wahl and Graw 2001; Norén et al. 2005; Ward et al. 2020; Boucherie et al. 2021). One of them is a technique based on the measurement of PP's lateral angle, known simply as the lateral angle (LA) method. As extensively presented in numerous publications on the subject (cf. e.g. Wahl 1981; Graw et al. 2005; Norén et al. 2005; Kozerska et al. 2020), regardless of the adult age categories or origins of individuals studied, there were significant differences between the size of the LA in both sexes. The method has already been applied for estimating the sex of cremated prehistoric individuals, for instance, those discovered at Stonehenge, dated to the Late Neolithic/ Early Bronze Age (Willis et al. 2016). Due to its applicability to individuals from cremation graves, the method gave basis also to the analyses of such prehistoric finds like the ones presented below.

\section{Material and methods}

The anthropological analyses were performed on cremated bone remains from the burial ground of the Urnfield culture discovered at site 2 in Czernikowice, Poland $\left(51.317389^{\circ} \mathrm{N}, 15.871469^{\circ} \mathrm{E}\right)$ (Stolarczyk et al. 2020). 
Osteological material was recovered in the 1960s and 1970s and since then most of it has been lost. Out of about 200 burials, cremains from just 24 features, i.e. 20 graves and 4 bone clusters, could have been reanalyzed. However, for 100 burials archival anthropological reports of Brunon Miszkiewicz survived, and these were included in the current analyses and interpretation of the burial ground (Stolarczyk et al. 2020).

The majority of the graves $(70.7 \%)$ are dated to the Bronze Age (BA) V, 8.8\% of them - to BA IV, $8.0 \%$ - to BA IV-V, and $3.2 \%$ - to the end of the Bronze Age and the beginning of the Early Iron Age. The remaining graves were dated generally to a long period lasting from the Late Bronze Age to the Early Iron Age, viz. around 1300-400 BC.

The weight of the cremated bones was measured for $11.1 \%$ burials and ranged from 2 to $1288 \mathrm{~g}$. Heavily burnt bone fragments $(97.4 \%)$ were of white, chalkwhite or cream colour.

The MNI value for 124 analysed graves and bone clusters was estimated to be 146 , of which age at death was determined in the case of 140 (95.2\%) individuals.

The division into age categories was used according to Kwiatkowska (2005): Infans I (younger children) - from 0 to 7 years old, Infans II (older children) - from 7 to 14 years old, Juvenis (youthful ones) - from 14 to 22 years old, Adultus (young adult) - from 22 to 35 years old, Maturus (middle adult) - from 35 to 55 years old, senilis (old adult) - over 55 years old. The most numerous age group was that of children (69.2\%: Infans I - 52.7\%, Infans II $-16.4 \%)$, less numerous was the set of adults $(13.0 \%)$, and the least numerous were the oldest individuals (1.5\%). Based on the estimated ages at death and mor- tality table, life expectancy at birth (e0) was estimated to be 6.5 years, whilst individuals in the reproductive age on average did not live past 30 years $\left(\mathrm{e}_{20}=8.9\right)$. The value of the potential reproduction index was high $\left(\mathrm{R}_{\text {pot }}=0.883\right)$, but so was the proportion of deaths in childhood (79.1\%). This situation was mirrored by a low value of the biological state index of the population $\left(\mathrm{I}_{\mathrm{bs}}=0.179\right)$, indicating its poor biological condition.

The sex of the individuals was estimated according to the methods proposed by Strzałko, Piontek, Malinowski (1973), based on morphological dimorphism of the skull and measurements of the zygomatic bone and the bones of the postcranial skeleton. The sex of most individuals was indeterminable (72.1\%). This was caused by the predomination of individuals classified within the youngest age categories (69.2\%). Based on standard anthropological methods, from among 146 individuals 22 were identified as males and 17 as females.

In the reanalysed osteological material, there were 6 well-preserved PP 4 right ones - PP R, and 2 left ones - PP L) that belonged to 6 different individuals of various ages at death and sex determined for 3 adult individuals using conventional anthropological methods (Strzałko et al. 1973; Dokládal 1999). The sex of these 3 adult individuals was determined on the basis of at least two features of the skull morphology (individuals from graves 69 and 78) and measurements of the bones of the postcranial skeleton (individuals from graves 78 and $\mathrm{Cz} / 18$ ). On this basis, it was determined that an individual from grave 69 had $80 \%$ probability of being male, and an individual from grave 78 with a $56 \%$ probability of being female (Strzałko et al. 1973; Stolarczyk et al. 2020). For the individual from grave 
78, the proximal femur epiphysis (head diameter) was measured, identifying this individual as female. Regarding an individual from the grave $\mathrm{Cz} / 18$, measurements of the humeral head and radius were taken and classified as male.

The identified PP offered an opportunity to apply the lateral angle (LA) method in order to assess the sex of individuals and determine the results for individuals whose sex was determined also with the use of standard anthropo- logical methods (Strzałko et al. 1973; Dokládal 1999; White et al. 2011; Stolarczyk et al. 2020).

The LA method relies on measuring the angle between the internal auditory canal and the medial surface of the petrous part of the temporal bone (Wahl 1981). In this study, we applied the variant of the LA method (Akansel et al. 2008) that is adapted to measurements of the lateral angle made on tomographic scans (Figure 1).

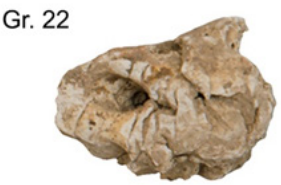

Gr. 74

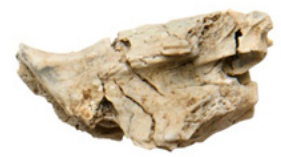

Gr. 82

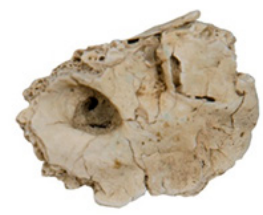

Gr. 69

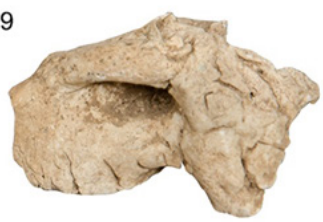

Gr. 78

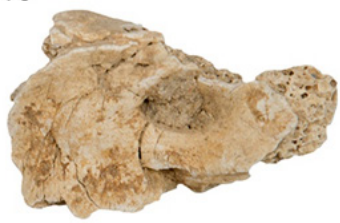

Gr. $\mathrm{Cz} / 18$

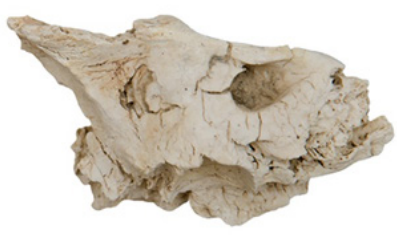

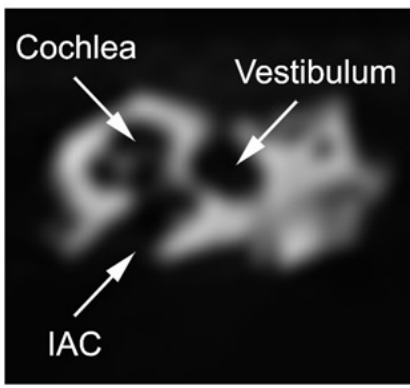

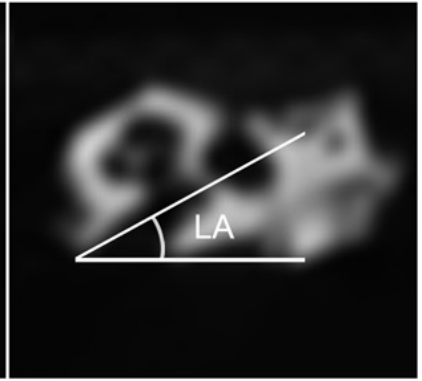

Fig. 1. Preserved petrous parts (PP) of temporal bones of individuals from cremation graves (Gr.) from the burial ground at Czernikowice and the technique of measuring lateral angle (LA). Bottom to the right the most easily recognizable inner ear structures: cochlea, vestibulum and internal acoustic canal (IAC). 
The CT examination of preserved PP was performed in the Department of General Interventional Radiology and Neuroradiology of the Wroclaw Medical University with a VCT Lightspeed, 64-row scanner (GE Healthcare, USA). The scanning parameters: tube voltage $120 \mathrm{kVp}$; beam collimation was $0.6 \mathrm{~mm}$; scan range cover all bones, scan rotation time was 1 s., automatic exposure control (AEC) was activated, the noise index (NI) was 2.8. Scanning was performed in sequential mode. The filtered back projection (FBP) algorithm was used for image reconstruction. Image matrix size of $512 \times 512$ was the standard for the CT application. Images were reconstructed in axial and coronal planes with a resolution ranging from 0.3 to $10.0 \mathrm{~mm}$, according to requirements. Image analyses were performed in soft tissue and bone window. Image post-processing techniques included $2 \mathrm{D}$ and $3 \mathrm{D}$ reconstructions (MPR - multiplanar reconstruction, MIP - maximum intensity projection, VR - volume rendering).

LA measurements on the CT scans of each PP were taken twice at monthly intervals. The intra-observer error was calculated on the basis of the absolute, as well as relative differences in values of measurements and their standard errors (SD; Popović and Thomas 2017). Additionally, technical errors of measurements (TEM) and relative technical errors of measurements (rTEM) were calculated. In this case, the latter is equivalent to the coefficient of variation expressed in percentage. Values of rTEM that are below $5 \%$ indicate that the repeated measurements were precise (Ulijaszek and Kerr 1999; Weinberg et al. 2005) and should be considered as reliable. A detailed intra-observer error analysis was made for each of the 6 investigated PP. Differences in results of measurements in accordance with age categories (between children and adults) and sex classes (between female and male individuals) were also verified. For each of the four categories, precision of measurements was verified by calculating their coefficient of reliability (R). $R$ values range between 0 and 1 , where those equal or close to the upper limit indicate that there was no measurement error (Weinberg et al. 2005). Differences in intra-observer errors for measurements on the left and right PP were not calculated, because there was only one preserved PP for each individual. As all the measurements were taken by a single person, inter-observer errors were not taken into consideration.

The sex of each individual was determined on the basis of the arithmetic mean of the LA measurements. he obtained value was then compared to and classified in accordance with the known ranges of its variation for male and female individuals. As a sectioning point $45.0^{\circ}$ was applied. Individuals for which the LA value was greater than or equal to $45.0^{\circ}$ were qualified as females and those for which it was less than $45.0^{\circ}-$ as males $\left(\mathrm{F} \geq 45^{\circ}<\mathrm{M}\right)$, (Wahl 1981; Norén et al. 2005; Akansel et al. 2008; Kozerska et al. 2020). The small sample of the PP was tested. Therefore the difference between the mean values of LA measurements performed for both the sexes was tested with the use of the non-parametric Mann-Whitney $U$-test.

\section{Results}

In the cases of individuals buried in graves 69,78 and $\mathrm{Cz} / 18$, their sex determinations based on standard anthropological methods were confirmed with the LA method (Table 1). Also, the lateral 
angle measurements made it possible to estimate the sex of children from graves 22,74 and 82 . Individuals from burials
74 and 82 were determined to be males, whereas the one from grave 22 - was female (Table 1).

Table 1. General characteristics of individuals and individual mean values of PP lateral angle with standard deviation $(\mathrm{SD})$; results of LA measurements are provided in degrees $\left({ }^{\circ}\right)$

\begin{tabular}{cccccc}
\hline $\begin{array}{c}\text { Grave } \\
\text { number }\end{array}$ & Age at death & $\begin{array}{c}\text { Standard sex } \\
\text { determination }\end{array}$ & $\begin{array}{c}\text { PP under } \\
\text { analysis }\end{array}$ & Mean \pm SD & $\begin{array}{c}\text { LA method sex } \\
\text { determination }\end{array}$ \\
\hline 22 & Infans I & Undetermined & Right & $48.0 \pm \mathbf{0 . 6}$ & Female \\
69 & Maturus & Male & Right & $36.5 \pm \mathbf{0 . 3}$ & Male \\
74 & Infans II & Undetermined & Right & $24.9 \pm \mathbf{0 . 6}$ & Male \\
78 & Adultus & Female & Left & $49.1 \pm \mathbf{0 . 9}$ & Female \\
82 & Infans I & Undetermined & Right & $34.7 \pm \mathbf{0 . 9}$ & Male \\
$\mathrm{C}$ /18 & Adultus/Maturus & Male & Left & $37.5 \pm \mathbf{0 . 4}$ & Male \\
\hline
\end{tabular}

The values of the LA angle ranged from 24.9 to $49.1^{\circ}$, with the mean of $38.4 \pm 9.02^{\circ}$. The LA values for female individuals fell in the range from 48.0 to $49.1^{\circ}$, with the mean value of $48.5 \pm 0.78^{\circ}$, and median of $48.4^{\circ}$. The LA values for male individuals fell in the range between 24.9 and $37.5^{\circ}$, with the mean value of $33.4 \pm 5,80^{\circ}$, and median of $35.5^{\circ}$ (Figure 2). The absolute difference between the mean values for female and male individuals was high $\left(15.1^{\circ}\right)$ and was proven to be statistically significant $(p<0.001$; Mann-Whitney $U$-test $)$. However, the low number of tested PP should be taken into account.

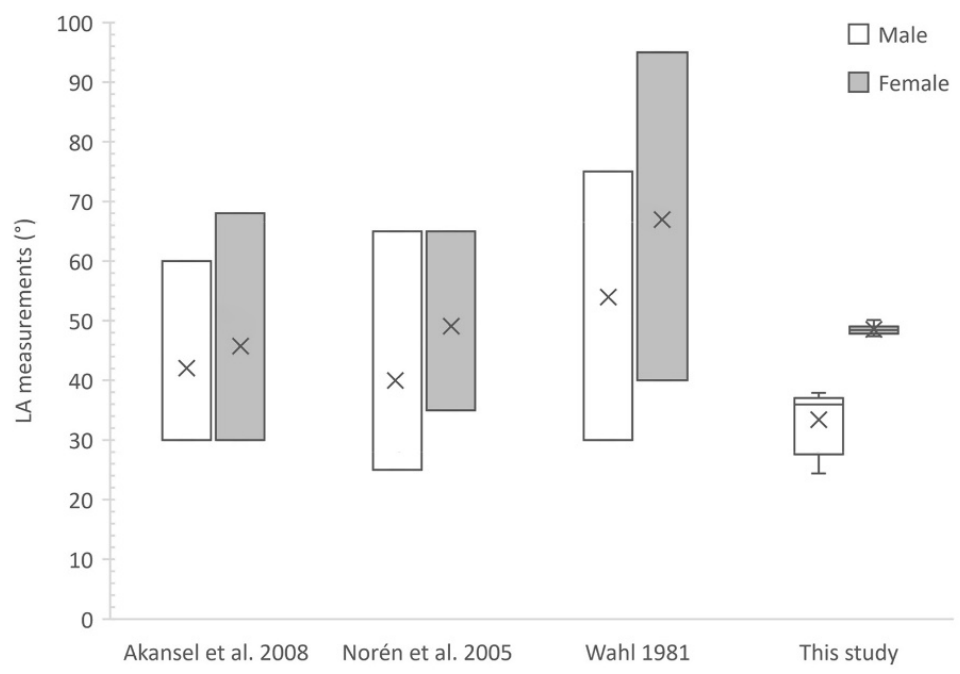

Fig. 2. Comparison between the results of lateral angle (LA) measurements on male and female individuals form Czernikowice with analogical ranges from selected studies (Wahl 1981; Norén et al. 2005; Akansel et al. 2008). 
The results obtained for intra-observer errors indicate high repeatability of the measurements. Absolute differences between values of every first and every repeated measurement were lower than $1.0^{\circ}$, and the relative technical error of measurement (rTEM) for particular individuals did not exceed
1.5\% (Table 2). There were no differences in the precision of the measurements, either in regard to the sex of individuals or their age at death. For all the categories, values of the coefficient of reliability (R) were close to 1.0 (Table $3)$, which confirms that the measurements were repeatable.

Table 2. Intra-observer errors calculated on the basis of absolute and relative variability values of measurements of lateral angles with their individual standard deviations (SD), as well as technical errors of measurements (TEM) with relative technical errors of measurements (rTEM)

\begin{tabular}{ccccccc}
\hline & \multicolumn{2}{c}{$\begin{array}{c}\text { Absolute intra-observer } \\
\text { variability }\end{array}$} & \multicolumn{2}{c}{$\begin{array}{c}\text { Relative intra-observer } \\
\text { variability }\end{array}$} \\
Grave number & Difference & Individual SD & Difference (\%) & Individual SD (\%) & TEM & rTEM \\
\hline 22 & 0.33 & 0.52 & 1.3 & 1.1 & 0.13 & 0.28 \\
69 & -0.40 & 0.28 & 1.0 & 0.8 & 0.16 & 0.45 \\
74 & 0.20 & 0.52 & 2.3 & 2.1 & 0.08 & 0.33 \\
78 & -0.93 & 0.80 & 2.0 & 1.6 & 0.52 & 1.07 \\
82 & -0.73 & 0.80 & 3.3 & 2.3 & 0.30 & 0.86 \\
$\mathrm{Cz} / 18$ & 0.53 & 0.38 & 1.3 & 1.0 & 0.22 & 0.58 \\
\hline
\end{tabular}

Table 3. Mean values of lateral angle (LA) measurements and the parameters of their errors with the coefficient of reliability (R) for individuals categorized according to sex and age-at-death; SD - standard deviation, TEM - technical error of measurement, rTEM - relative technical error of measurement

\begin{tabular}{ccccc}
\hline Category & Mean \pm SD & TEM & rTEM & R \\
\hline Children & $35.8 \pm 10.6$ & 0.19 & 0.54 & 0.9996 \\
Adults & $41.0 \pm 6.06$ & 0.27 & 0.66 & 0.9980 \\
Female & $48.5 \pm 0.90$ & 0.28 & 0.59 & 0.9036 \\
Male & $33.4 \pm 5.27$ & 0.21 & 0.62 & 0.9984 \\
\hline
\end{tabular}

\section{Discussion}

The process of cremation negatively affects the potential of anthropological analyses performed on human remains. A vast majority of the Lusatian culture cremains belong to individuals of the subadult age category (Szybowicz 1995; Stolarczyk et al. 2020). Reliable assessment of their sex would be of great importance not only for reconstructions of sex structures within the population but also for approaching socio-cultural issues.

The LA method is among very few procedures of sex estimation that are applicable to cremated human remains from archaeological contexts (Wahl 1981). It must be stressed, that hitherto 
no research on PP alterations (including changes of LA) caused by the process of cremation has been conducted (Gonçalves et al. 2015). However, the studies based on modern cremains of adult individuals have demonstrated that LA values can correspond with their actual sex (Masotti et al. 2013). Additionally, the research confirmed that there were no statistically significant differences between LA measurements taken on the right versus those taken on the left PP of a given individual (Gonçalves et al. 2015; Afacan et al. 2017; Kozerska et al. 2020; Bonczarowska et al. 2021). The LA method has been tested on subadult individuals, but despite statistically significant differences between both sexes (Gonçalves et al. 2011), its use in sex estimation in children and juvenile is questioned (Akansel et al. 2008; Gonçalves et al. 2011; Afacan et al. 2017; Kozerska et al. 2020), and in a recent study its effectiveness is uncertain even for adults (Bonczarowska et al. 2021).

Conducted clinical research also has not confirmed differences between female and male individuals to be statistically significant (Morgan et al. 2013). Moreover, some scholars point out the unreliability of the results regarding subadult individuals and those over the age of 70, showing large discrepancies between the already known sex and the one estimated on the basis of LA measurements (Masotti et al. 2013; Afacan et al. 2017; Masotti et al. 2019|. The applicability of the LA method for sexing subadult individuals has been challenged by Afacan et al. (2017). Their research conducted on individuals in the age range from 0-18 years showed no differences between the sexes, but age-related decrease of LA values were observed, especially in subadult male individuals. Similar age-related ob- servations have been reported by Akansel et al. (2008). The method applied by Afacan et al. (2017) was based on the lateral angle measurements taken on images obtained with magnetic resonance (MRI), and the sample group consisted of children with different pathologies of hearing organs, excluding patients with severe pathologies from the study. Therefore, even the authors themselves could not exclude the possibility that their research was conducted on a biased sample and that the measurements were collected disregarding the previous procedure (Wahl 1981; Graw et al. 2005).

Initially, the LA method was based on the measurements of the angle taken on a cast of the internal acoustic canal (IAC) made of dental casting material (Wahl 1981; Graw et al. 2005; Norén et al. 2005; Gonçalves et al. 2011). However simple the technique may appear, either preparation of the casts without damaging cremated bones, or repeatable LA measurements made on them, were never easy to perform. Therefore, the technique was improved by intersecting the silicone replicas with the aim of making their photocopies or scans. The measurements were firstly taken manually on paper copies (Graw et al. 2005), and then on digital copies with the use of computer software (Gonçalves et al. 2011). From a bioarchaeological point of view, the most critical phase of the procedure is the operation performed prior to casting the silicon replicas of the IAC. For the ease of extracting solidified silicone-based material, the outer surface of PP and the inner surface of the IAC must be covered with vaseline or other substances with similar properties. Since PP are commonly subject also to biochemical analyses, including isotopic ones (Harvig et al. 2014; Chmielewski et al. 2021), any contamination with modern 
matter must not be accepted. Currently used non-invasive methods based on computed tomography are more appropriate for the frangible and otherwise sensitive archaeological osseous material (Akansel et al. 2008; Panenková et al. 2009; Morgan et al. 2013; Willis et al. 2016; Afacan et al. 2017; Gibelli et al. 2021; Pezo-Lanfranco and Haetinger 2021).

Based on the investigation conducted on the 6 PP from the burial ground at Czernikowice, it can be argued that the difficulties in applying CT scans to LA measurements result first and foremost from poor preservation of the bone structures. Additionally, any contamination of anatomical structures of PP with sediments also limit the possibility of their digital imaging and thereby correct measuring of the lateral angle. Moreover, sincepetrous parts of temporal bones are usually separated from skulls, placing them in the gantry of a scanner in their anatomical position can be difficult. Consequently, in some cases, the measurement of the LA value must be taken on MPR or VR reconstructions instead of axial reconstructions. However, regarding the PP investigated within the present study, this had no effect on the repeatability of the measurements.

Various authors have been concerned about low values of technical errors for both intra- as well as inter-observer measurements (Norén et al. 2005; Pezo-Lanfranco and Haetinger 2021). Discrepancies between the repeated intra-observer measurements taken for the needs of the mentioned studies generally did not exceed $1^{\circ}$, and the highest rTEM was approximately $1 \%$. However, in some research, the value of intra-observer error was above the threshold of acceptance. This indicates that the overall reproducibility of measurements was not precise, while their repeatability (coherence of measurements taken by a single observer) was maintained (Gonçalves et al. 2011; Gonçalves et al. 2015).

The most serious problem though, is the considerable overlap of LA ranges measured for female and male individuals (Pezo-Lanfranco and Haetinger 2021; see Figure 2). In some studies, the differences between mean values of measurements taken for individuals of the two sexes turned out to be statistically insignificant (Morgan et al. 2013; Gonçalves et al. 2015). Nevertheless, the majority of works has already proven the difference to be statistically significant (Graw et al. 2005; Norén et al. 2005; Akansel et al. 2008; Masotti et al. 2019|. However, even in these cases, the thresholds of discrimination between LA ranges for both the sexes differ considerably. The most often provided value is that of $45^{\circ}$ (Norén et al. 2005; Akansel et al. 2008), but others report $41^{\circ}$ (Masotti et al. 2019). Akansel et al. (2008) not only measured the threshold at $45^{\circ}$ but also determined the probability of discrimination between both sexes. Scholars calculated the limit value of $60^{\circ}$ for female individuals, where such determination of sex has a $97 \%$ probability, and the limit value of $35^{\circ}$ for male individuals, below which such sex determination hasa 93\% probability. Similarly, Graw et al. (2005) provide the value of $65^{\circ}$ for females and $40^{\circ}$ for males. In our study, the threshold of $45^{\circ}$ was accepted, and individuals for which values were lower than $40^{\circ}$ were regarded as being males. The difference between the mean values calculated for both the sexes was considerable and statistically significant, though it must be underlined that the analysed sample was very small (just 6 individuals).

Other important questions raised in works addressing the subject concern the 
specificity of studied populations and possible differences between the cremation as it is carried out nowadays, and the way it was performed in prehistory. Modern human populations that were investigated in regard to LA variability are characterized by a relatively low phenotypic variability (Pezo-Lanfranco and Haetinger 2021). For that reason outcomes of these studies might be irrelevant to the results of analogical research conducted on prehistoric populations, which have been characterized by a stronger dimorphism of LA. The morphological diversity concerns also the shape of the IAC. There are few main morphotypes of the IAC that can be distinguished within modern populations: the funnel-shaped, the cylinder-shaped and the bud-shaped one (Marques et al. 2012). The variability is of great significance for performing LA measurements. Therefore, when applying the variant of the LA method that uses tomograms, it is proposed to take the LA measurement starting from the apex of the IAC instead of measuring it parallel to the anterior lip of the IAC (Akansel et al. 2008; Gibelli et al. 2021; Pezo-Lanfranco and Haetinger 2021). However, not all researchers using the LA method based on CT imaging take the lateral angle measurement in the exact same way (Panenková et al. 2009; Morgan et al. 2013; Afacan et al. 2017). This causes problems when comparing research results, both in regard to the obtained LA ranges, as well as threshold values discriminating individuals between the sexes. Therefore, the determinations of LA ranges and thresholds for sexing individuals from archaeological contexts should be, at best, based on statistical calculations made for each investigated population (burial ground).

With regards to the burial ground from Czernikowice, the difference between the sexes was apparent (Table 3), although it must be kept in mind that the number of studied individuals was low. In the case of three adult individuals, sexing with the use of the LA method confirmed the results of earlier analyses based on standard anthropological procedures. Based on the adopted sectioning point $45^{\circ}\left(\mathrm{F} \geq 45^{\circ}<\mathrm{M}\right)$, the sex of subadult individuals was estimated (Table 1). No other method would allow determining the sex of subadult individuals on the basis of their cremains. However, although the LA method seems to be a promising tool for estimating sex of cremated human bones, there is no certainty that the estimated sex is the "real sex", especially for infant and juvenile individuals (Akansel et al. 2008; Afacan et al. 2017).

\section{Conclusions}

The LA method based on CT imaging, despite being widely questioned, can be applied to cremated osteological material from archaeological contexts. The use of computed tomography scanning makes the method non-invasive, non-destructive, thereby enhancing its value. The method is also relatively inexpensive. However, poor preservation of inner anatomical structures of the petrous bone and its possible high density contamination with sediments can limit the effective use of the technique.

The LA method can be applied as an ancillary protocol of sex estimation in regard to adult individuals from archaeological contexts. However, its applicability to the subadult individuals should be approached with caution, calling for further comparative studies, as do the effects of the process of cremation on the morphology of petrous parts of temporal bones, as well as age-related developmental changes. 


\section{Acknowledgements}

We would like to express our gratitude to Tomasz Stolarczyk and Przemysław Paruzel from the Copper Museum in Legnica (Poland) for providing us with archival anthropological reports and the osteological material for analyses. We would also like to thank the anonymous reviewers for significant comments that improved the manuscript.

This publication was financed by the Minister of Science and Higher Education (Grant No DNK/SP/463728/2020): Excellent Science - Support for scientific conferences. Funeralia Gnieźnieńskie Man in the perspective of interdisciplinary research.

Computed tomography and the analyses of resulting data were performed under research project no. UMO$2018 / 29 /$ N/HS3/00887, funded by the National Science Centre, Poland.

\section{Authors' contributions}

$\mathrm{AH}$ designed the research and secured its financing. MG completed and reported computed tomography. The resulting data were analysed and interpreted by $\mathrm{AH}$. The paper was drafted and revised by $\mathrm{AH}$ and approved by MG.

\section{Conflict of interest}

The authors declare that there is no conflict of interest.

\section{Corresponding author}

Agata Hałuszko, Institute of Archaeology, University of Wrocław, Szewska 48, 50-137 Wrocław, Poland.

E-mail: agata@archeolodzy.org

\section{References}

Afacan GO, Onal T, Akansel G, Arslan AS. 2017. Is the lateral angle of the internal acoustic canal sexually dimorphic in nonadults? An investigation by routine cranial magnetic resonance imaging. HOMO 68(5):393-7. https://doi.org/10.1016/j.jchb. 2017.09.001

Akansel G, Inan N, Kurtas O, Sarisoy HT, Arslan A, Demirci A. 2008. Gender and the lateral angle of the internal acoustic canal meatus as measured on computerized tomography of the temporal bone. Forensic Sci Int 178(2-3):93-5. https://doi. org/10.1016/j.forsciint.2008.02.006

Bonczarowska JH, McWhirter Z, Kranioti EF. 2021. Sexual dimorphism of the lateral angle: Is it really applicable in forensic sex estimation? Arch Oral Biol 124:105052. https:// doi.org/10.1016/j.archoralbio.2021.105052

Boucherie A, Polet C, Lefèvre P, Vercauteren M. 2021. Sexing the bony labyrinth: A morphometric investigation in a subadult and adult Belgian identified sample. J Forensic Sci 66(3):808-20. https://doi. org/10.1111/1556-4029.14663

Chmielewski TJ, Hałuszko A, Goslar T, Cheronet $\mathrm{O}$, Hajdu T, Szeniczey $\mathrm{T}$, Virag C. 2021. Increase in $14 \mathrm{c}$ dating accuracy of prehistoric skeletal remains by optimised bone sampling: Chronometric studies on eneolithic burials from Mikulin 9 (Poland) and Urziceni-Vada Ret (Romania). Geochronometria 47:196-208. https://doi. org/10.2478/geochr-2020-0026

Dokládal M. 1999. Morfologie spálenỳch kostí. V znam pro identifikaci osob. Lékařská Fakulta Masarykovy Univerzity v Brně.

Gibelli D, Cellina M, Gibelli S, Termine G, Oliva G, Sforza C, Cattaneo C. 2021. Relationship between lateral angle and shape of internal acoustic canal: Cautionary note for diagnosis of sex. Int J Leg Med 135(2):687-92. https:// doi.org/10.1007/s00414-020-02400-2 
Gonçalves D, Campanacho V, Cardoso HF. 2011. Reliability of the lateral angle of the internal auditory canal for sex determination of subadult skeletal remains. J Forensic Leg Med 18(3):121-4. https:// doi.org/10.1016/j.jflm.2011.01.008

Gonçalves D, Thompson T, Cunha E. 2015. Sexual dimorphism of the lateral angle of the internal auditory canal and its potential for sex estimation of burned human skeletal remains. Int J Leg Med. 129:1183-6. https://doi.org/10.1007/ s00414-015-1154-x

Gowland R, Stewart NA, Crowder KD, Hodson C, Shaw H, Gron KJ, Montgomery J. 2021. Sex estimation of teeth at different developmental stages using dimorphic enamel peptide analysis. AJPA 174 (4):85969. https://doi.org/10.1002/ajpa.24231

Graw M, Wahl J, Ahlbrecht M. 2005. Course of the meatus acusticus internus as criterion for sex differentiation. Forensic Sci Int. 147(2-3):113-7. https://doi.org/10.1016/j. forsciint.2004.08.006

Harvig L, Frei KM, Price TD, Lynnerup N. 2014. Strontium isotope signals in cremated petrous portions as indicator for childhood origin. PloS ONE 9(7):e101603. https://doi.org/10.1371/journal.pone. 0101603

Kozerska M, Szczepanek A, Tarasiuk J, Wroński S. 2020. Micro-CT analysis of the internal acoustic meatus angles as a method of sex estimation in skeletal remains. HOMO 71(2):121-28. https://doi. org/10.1127/homo/2020/1133

Kwiatkowska B. 2005. Mieszkańcy średniowiecznego Wrocławia. Ocena warunków życia i stanu zdrowia w ujęciu antropologicznym. Wrocław: Wydawnictwo Uniwersytetu Wrocławskiego.

Lasak I. 1996. Epoka brązu na pograniczu śląsko-wielkopolskim, Część I-Materiały źródłowe. Wrocław: Katedra Archeologii, UWr.
Loth SR, Henneberg M. 2001. Sexually dimorphic mandibular morphology in the first few years of life. AJPA 115(2):179-86. https://doi.org/10.1002/ajpa.1067

Marques SR, Ajzen S, D Ippolito G, Alonso L, Isotani S, Lederman H. 2012. Morphometric analysis of the internal auditory canal by computed tomography imaging. Iran J Radiol 9(2):71-78. https://doi. org/10.5812/iranjradiol.7849

Masotti S, Pasini A, Gualdi-Russo E. 2019. Sex determination in cremated human remains using the lateral angle of the pars petrosa ossis temporalis: Is old age a limiting factor? Forensic Sci Med Pat 15:39298. https://doi.org/10.1007/s12024-01900131-4

Masotti S, Succi-Leonelli E, Gualdi-Russo E. 2013. Cremated human remains: Is measurement of the lateral angle of the meatus acusticus internus a reliable method of sex determination? Int J Leg Med 127(5):1039-44.https://doi.org/10.1007/ s00414-013-0822-y

McKinley JI. 2015. In the Heat of the Pyre. In: Schmidt C, Symes S, editors. The Analysis of Burned Human Remains. Elsevier: Academic press 181-202. https:// doi.org/10.1016/B978-0-12-8004517.00010-3

Morgan J, Lynnerup N, Hoppa RD. 2013. The lateral angle revisited: a validation study of the reliability of the lateral angle method for sex determination using computed tomography (CT). J Forensic Sci 58(2):443-47. https://doi. org/10.1111/1556-4029.12090

Norén A, Lynnerup N, Czarnetzki A, Graw M. 2005. Lateral angle: A method for sexing using the petrous bone. AJPA 128(2):318-23. https://doi.org/10.1002/ ajpa. 20245

Panenková P, Benus R, Masnicová S, Hojsök D, Katina S. 2009. Reliability of sex estimation by lateral angle method and 
metric analysis of the foramen magnum. In: Proceedings of the 5th International Anthropological Congress of Ales Hrdlicka; 2-5 Sept 2009.

Pezo-Lanfranco L, Haetinger R. 2021. Tomographic-cephalometric evaluation of the pars petrosa of temporal bone as sexing method. Forensic Sci Int: Rep 3:100174. https://doi.org/10.1016/j.fsir.2021.100174 Popović ZB, Thomas JD. 2017. Assessing observer variability: a user's guide. CDT 7(3):317. https://doi.org/10.21037/ cdt.2017.03.12

Rebay-Salisbury K, Janker L, Pany-Kucera D, Schuster D, Spannagl-Steiner M, Waltenberger L, Salisbury RB, Kanz F. 2020. Child murder in the Early Bronze Age: Proteomic sex identification of a cold case from Schleinbach, Austria. Arch and Ant Sci 12(11):1-13. https://doi.org/10.1007/ s12520-020-01199-8

Schutkowski H. 1993. Sex determination of infant and juvenile skeletons: I. Morphognostic features. AJPA 90(2):199-205. https://doi.org/10.1002/ajpa.1330900206

Schutkowski H, Herrmann B. 1983. Zur Möglichkeit der metrischen Geschlechtsdiagnose an der Pars petrosa ossis temporalis. Zeit Rechts Med 90(3):219-27. https://doi.org/10.1007/BF02116233

Stolarczyk T, Paruzel P, Łaciak D, Baron J, Hałuszko A, Jarysz R, Kuźbik R, Łucejko JJ, Maciejewski M, Nowak Kamil. 2020. Czernikowice. Cmentarzyska z epoki brązu i wczesnej epoki żelaza. 1st ed. Legnica: Muzeum Miedzi w Legnicy.

Strzałko J, Piontek J, Malinowski A. 1973. Teoretyczno-metodyczne podstawy badań kości z grobów ciałopalnych. Mat Pra Ant 85:179-201.

Szybowicz B. 1995. Struktura populacji ludności grupy górnośląsko-małopolskiej kultury łużyckiej. ŚPP 4:375-85.

Ulijaszek SJ, Kerr DA. 1999. Anthropometric measurement error and the assessment of nutritional status. British J Nut 82(3):165-77. https://doi.org/10.1017/ S0007114599001348

Wahl J. 1981. Ein Beitrag zur metrischen Geschlechtsdiagnose verbrannter und unverbrannter menschlicher Knochenreste ausgearbeitet an der Pars petrosa ossis temporalis. Zeit Rechts Med 86:79-101. https://doi.org/10.1007/BF00201275

Wahl J, Graw M. 2001. Metric sex differentiation of the pars petrosa ossis temporalis. Int J Leg Med 114(4):215-23. https://doi. org/10.1007/s004140000167

Ward DL, Pomeroy E, Schroeder L, Viola TB, Silcox MT, Stock JT. 2020. Can bony labyrinth dimensions predict biological sex in archaeological samples? JAS: Reports. 31:102354. https://doi.org/10.1016/j.jasrep.2020.102354

Weinberg SM, Scott NM, Neiswanger K, Marazita ML. 2005. Intraobserver error associated with measurements of the hand. Am J Hum Bio 17(3):368-71. https://doi.org/10.1002/ajhb.20129

White TD, Black MT, Folkens PA. 2011. Human osteology. Elsevier: Academic press.

Willis C, Marshall P, McKinley J, Pitts M, Pollard J, Richards C, Richards J, Thomas J, Waldron T, Welham K. 2016. The dead of Stonehenge. Ant J 90(350):337-56 https:// doi.org/10.15184/aqy.2016.26 